\title{
Profile of Victims of Motorcycle Accidents Admitted in Emergency Room of a Public Hospital in Ceara, Brazil

\begin{abstract}
Cícero Valdizébio Pereira Agra1, Italla Maria Pinheiro Bezerra1,2,Sophia Cornbluth Szarfarc², Joao Kennedy Teixeira Lima', Luiz Carlos de Abreu ${ }^{1}$
\end{abstract}

\section{Abstract}

Introduction: Economic growth and the increase of credit power in Brazil, especially in the Northeast region, allow the population to increase the acquisition of vehicles, mostly motorcycles. On the other hand, while facilitated this sale, little is invested in traffic enforcement measures, in an alarming increase of traffic accidents associated with causes that could be avoided, resulting in several members and head traumas or can lead to death.

Objective: To describe the profile of motorcycle accident victims who were admitted in the emergency room of a public hospital.

Methods: This is a descriptive, retrospective, documentary and quantitative study carried out with 270 victims of brain trauma involved in motorcycle accidents admitted in a public hospital in Ceará, Brazil. Data collection happened between 2013 and 2014, analyzing medical records of patients and answering a basic form for data optimization.

Results: Motorcycle accidents that occurred in the period 2013-2014 registered in the public hospital of the city of Cariri, Ceará, Brazil, affecting mostly males (88.1\%) and a high number of young people and adults (55\%). There has been a reduction of accidents from 2013 (65\%) and 2014 (34.1\%). There was a predominance of accidents over the weekend (41\%), having as a contributing factor alcoholism (61\%) and the non-use of a helmet (86\%), providing the skull trauma injury as the most present (40.7\%).
1 Laboratório de Delineamento de Estudos e Escrita Científica da Faculdade de Medicina do ABC, Santo André, São Paulo, Brasil.

2 Laboratório de Delineamento de Estudos e Escrita Científica. EMESCAM, Escola Superior de Ciências da Santa Casa de Misericórdia de Vitória.

Contact information:

Italla Maria Pinheiro Bezerra.

झ" itallamaria@hotmail.com 
Conclusion: The characterization of patients shows that the brain and facial traumas are related directly to the use of the helmet, not associated with other causes such as age group, alcohol use and lack of supervision in the municipalities, also is important to stand out the need to to strengthening and creating public policies in order to prevent damages.

\section{Keywords}

Motorcycle Accidents; External Causes; Public Health Policies.

\section{Introduction}

Automobile accidents, in particular those with motorcycles, constitute a serious public health issue, in particular by physical limitations arising in their survivors, influencing on social determinants of health, since these are social, economic, ethnic/racial, cultural, behavioral and psychological factors influencing the occurrence of health problems and their risk factors in the population.

In the face of technological advances, increasing the purchasing power of the world's population and the accelerated process of urbanization, it has been observed in recent years, a great evolution in the number of people who own transport like cars or motorcycles, to perform their daily activities or as a working tool.

On the other hand, especially in developing countries, a disorganized growth reflected by the poor organization of traffic and the excessive number of accidents, causes fatalities or serious sequelae, in most cases, to drivers of motorcycles. According to the World Health Organization, approximately 1.3 million people die of traffic accident victims every year, and the most vulnerable groups (bikers, pedestrians and cyclists) found more than half of this value, concentrating in Africa the most dangerous and deadly world transits [1].

In Brazil, the economic growth, particularly in the Northeast, with expansion of income and personal loans, combined with a chronic deficiency in public transport, provided a significant increase in the purchase of motor vehicles, especially the various models of motorcycles.

The acquisition of the means of transport, either for work or for leisure, by the population brought, in good part, negative consequences, in view of the large number of accidents involving these vehicles with severe traumas, which if does not lead to death, leave sequelae, in most cases disabled people, leading to a problem consider itself as a serious public health issue [2-5].

In the Brazilian State of Ceará, the reality presented above comes with the same pace, the increase in the number of motorcycle acquisition, justified by the lack of investment in public transport, also for facilitating the movement of people in traffic, have low fuel consumption, purchase price and maintenance more accessible than most cars [6].

In contrast to the fast growth of large cities, where traffic control measures are more accurate and punctual, the municipalities mainly in the North and Northeast regions still suffer from a lack of this, resulting in the misuse of motorcycles, where drivers usually don't carry permission to drive, do not wear helmets and have their vehicles in irregular conditions for circulation. However, the immense facility for the purchase of these vehicles that is disproportionate to the number of preventive measures adopted for the correct usage [7].

Because of this significant increase of vehicles and motorcycles and the high frequency of inappropriate behaviors among drivers, car accidents become 
an important cause of traumas and death, especially among the young population [8].

In Brazil, the mortality of users of two-wheel motor vehicle increased by more than $700 \%$ since the implementation of the Brazilian traffic code (CTB), in 1998. The riders went from 3\% (1998) to $23 \%$ (2008) of the total number of deaths from traffic accidents in the country [9]. Between 1998 and 2006, motorcycle accidents have generated high costs for Brazilian society, with estimates of 5.3 billion reais (Brazilian local currency) spending in the period [10].

Since the 1980s, the violence and the injuries have been prominent causes of morbidity and mortality in Brazil; until 2007, accounted for $12.5 \%$ of deaths, especially among young men (83.5\%). Although various initiatives may have contributed to the reduction of deaths and injuries related to traffic in Brazil, the rates remain high in many countries in Latin America and not yet is sufficient known about its effectiveness, since there are few studies to evaluate such interventions [11].

The damage to health because of these accidents can achieve different dimensions, resulting in physical and emotional effects, which reduce the quality of life in individual and collective levels and generate overload to health services.

Mesquita et al. [12], analyzing hospital costs generated by external causes in the emergency room of a large hospital in Teresina, Piauí, Brazil, identified, between 2005 and 2007, spending in local currency of $R \$ 1,019,755.90$ with admissions by external causes, i.e. higher compared to other causes in the same period ( $R \$ 44.888,912)$.

In addition, it should be noted that the external demand causes more complex hospital procedures, with greater number of surgeries, need of intensive therapy, drug consumption and multi-professional support, resulting in high costs to health services [12].

Therefore, the health resources to achieve recovery of the victims of traffic accidents, especially motorcyclists, in virtue of the lesions being usually serious, are still flawed and basic.
In this way, it is important to evaluate the characteristics that result in accidents to work on these points in order to prevent diseases and reduce the number of accidents by external causes for the traffic.

Thus, the objective of this study is to describe the profile of motorcycle accident victims admitted in emergency room of a public Hospital.

\section{Methods}

This is a descriptive, retrospective, documentary and quantitative study, carried out with 270 individuals involved in motorcycle accidents admitted in a public Hospital in Cariri, Ceara State, Northeast region of Brazil.

The participants were selected according to the inclusion criteria: patients who had complete documentation during the medical interventions; who were transiting in a motorcycle and who had hospitalization of at least five days.

Data collection happened between 2013 and 2014, where selected patients who had full documentation during the medical interventions, as well as had a motorcycle. Where analyzed the medical records of patients and transcribed the information for a simple form, seeking to optimize and understand the profile of the patients, which the most common consequence of these accidents, alcohol and helmet use and the weekly period in which there was the occurrence.

The data were entered and stored in spreadsheets of the Microsoft Excel 2007, defining the objective and results in numbers and percentage.

This study follows the ethical principles for research with human beings, as National Health Council resolution 466/12 and obtained opinion approved by the Committee of ethics in research of the Faculdade de Medicina do ABC, according to CONEP document $n^{\circ} 466 / 12$ adopted on February $15^{\text {th }}, 2012$. 


\section{Results}

Table 1 shows that the vast majority of accidents happened with males (88.1\%), having as a victim mostly about of $54 \%$ of people in the age of 10 to 29 years, affecting from highest form drivers $(88.2 \%)$, happening mostly on weekends, whereas the number of days in proportion (41.9\%). It is possible to see a reduction of accidents between 2013 and 2014.

Table 1. Profile of causalities according to gender, role in the accident, year and weekly period, Barbalha, Ceará, Brazil 2015.

\begin{tabular}{|l|c|c|}
\hline \multicolumn{1}{|c|}{ Characteristics } & N & $\%$ \\
\hline Gender & & \\
\hline Male & 238 & 88.1 \\
\hline Female & 32 & 11.9 \\
\hline Total & 270 & 100 \\
\hline Age (years) & & \\
\hline 0 a 9 & 09 & 3.3 \\
\hline 10 a 19 & 64 & 23.7 \\
\hline 20 a 29 & 86 & 31.9 \\
\hline 30 a 39 & 62 & 23.0 \\
\hline 40 a 49 & 27 & 10.0 \\
\hline Over 50 & 22 & 8.1 \\
\hline Role in the accident Conductor & & \\
\hline Passenger & 238 & 88.2 \\
\hline Trampling victim & 12 & 4.4 \\
\hline Total & 20 & 7.4 \\
\hline Social Participation & 270 & 100 \\
\hline Years & & \\
\hline 2013 & 178 & 65.9 \\
\hline 2014 & 92 & 34.1 \\
\hline Total & 270 & 100 \\
\hline Week period & & \\
\hline Working days & 157 & 58.1 \\
\hline Holidays and weekends & 113 & 41.9 \\
\hline Total & 270 & 100 \\
\hline & & \\
\hline
\end{tabular}

Source: Direct research between the years 2013 and 2014.
It is called attention to the non-use of helmets in both genders, with about of $86.7 \%$. That there is a greater intake of alcohol in males (59.6\%), which implies directly on the possible causes of accidents of respondents as described in Table $\mathbf{2}$.

Among the traumas resulting from accidents the most frequent was the brain trauma in terms of use (5.3\%) and non-use (35.4\%) of helmet, followed by facial trauma and trauma in upper limb, as shown in Table 3.

Table 2. Factors that influence in te motorcycle accident, Barbalha, Ceará, Brazil 2015.

\begin{tabular}{l|c|c|c|c|c|c|c|}
\hline \multirow{2}{*}{$\begin{array}{l}\text { Factors that } \\
\text { influence }\end{array}$} & \multicolumn{2}{|c|}{ Men } & \multicolumn{2}{c|}{ Women } & \multicolumn{2}{c|}{ Total } \\
\cline { 2 - 8 } & $n$ & $\%$ & $n$ & $\%$ & $n$ & $\%$ \\
\hline Use of helmet & & & & & & \\
\hline Use & 24 & 8.9 & 12 & 4.4 & 36 & 13.3 \\
\hline Non-use & 214 & 79.3 & 20 & 7.4 & 234 & 86.7 \\
\hline Total & 238 & 88.2 & 32 & 11.8 & 270 & 100 \\
\hline Alcohol ingestion & & & & & \\
\hline Ingestion & 161 & 59.6 & 5 & 1.9 & 166 & 61.5 \\
\hline Non-ingestion & 77 & 28.5 & 27 & 10 & 104 & 38.5 \\
\hline Total & 238 & 8.1 & 32 & 11.9 & 270 & 100 \\
\hline \multicolumn{1}{|c}{ Source: Direct research between the years 2013 and 2014.} \\
\hline
\end{tabular}

Table 3. Comparison of trauma resulting in the use and non-use of helmets, Barbalha, Ceará, Brazil, 2015.

\begin{tabular}{|l|c|c|c|c|c|c|}
\hline \multirow{2}{*}{ Traumas } & \multicolumn{3}{c|}{ Helmet use } & \multicolumn{2}{c|}{ Non-use } & \multicolumn{2}{c|}{ Total } \\
\cline { 2 - 8 } & $\mathrm{n}$ & $\%$ & $\mathrm{n}$ & $\%$ & $\mathrm{n}$ & $\%$ \\
\hline Brain Trauma & 35 & 5.3 & 233 & 35.4 & 268 & 40.7 \\
\hline Spinal Trauma & 3 & 0.5 & 6 & 0.9 & 9 & 1.4 \\
\hline Facial Trauma & 20 & 3.0 & 137 & 20.8 & 157 & 23.8 \\
\hline Thoracic Trauma & 2 & 0.3 & 10 & 1.5 & 12 & 1.8 \\
\hline Abdominal Trauma & 0 & 0.0 & 5 & 0.8 & 5 & 0.8 \\
\hline Pelvic Trauma & 0 & 0.0 & 2 & 0.3 & 2 & 0.3 \\
\hline Upper limb Trauma & 14 & 2.1 & 113 & 17.1 & 127 & 19.2 \\
\hline Lower limb Trauma & 11 & 1.7 & 66 & 10.0 & 77 & 11.7 \\
\hline No trauma & 1 & 0.15 & 1 & 0.15 & 2 & 0.3 \\
\hline Total & 86 & 13.05 & 573 & 6.95 & 659 & 100 \\
\hline \multicolumn{1}{|c|}{ Source: Direct research between the years 2013 and 2014.} \\
\hline
\end{tabular}




\section{Discussion}

The results illustrated that motorcycle accidents that occurred in the period 2013-2014 registered in the public hospital of the region do Cariri, Ceará, Brazil, affecting mostly males (88.1\%), affecting a high number of young people and adults (55\%). There was a predominance of accidents over the weekend (42\%) as these are understood only by three days. The accidents had use of alcohol (61\%) and the non-use of the helmet (86\%) as a contributing factor, having brain trauma as the most frequent (40.7\%), mainly because it is a hospital that attends in most cases, this specialty.

The predominance of males is common in traffic accidents, as shown in several national and international studies [13-16]. This can explain why, in most cases, these are the drivers of the vehicles involved, the largest group with a license to drive and have learned to handle even with minor age, leading to feelings of superiority and omnipotence in traffic.

Statistical data show that males have less pathologies than women, with a view to the physiological and hormonal process of each. However, men have higher mortality rate due to its involvement in external causes such as accidents, violence and other cases $[17,18]$.

External causes are considered by the World Health Organization an important public health problem in the world, often the second or third leading cause of deaths $[19,20]$. WHO [21] points out that the main factors causing deaths by external causes are related to socio-economic disparities, political and cultural, hitting mainly to male [22].

Such male participation in traffic accidents can also be caused by the history that permeates this people, considering that this is a being who in the past represented families, leading them and showing its grandeur to the other, especially in questions of health, on the assumption, that this can get ill [23, 24].

Currently, this pattern has reversed, because women are empowering themselves from their homes and often leading them, also reaching a greater number of female people who own and drive daily, as well as vehicles, have greater involvement in external causes [25]. What can prove this is the rate of women in the historical study presented in the literature, corroborating with the results of this [17, 26].

By analyzing historical retrospect of traffic accidents, it was observed that the predominance of males varied from about $70 \%$ to $90 \%$ [27], this index, which in most cases remains, as in the present study, but which has presented few changes with greater space gained by women

In the study of Soriano et al., [28] when performing a retrospective examining the socio-demographic variables between the years 2001 to 2010, it is observed that men exhibit increase in their involvement in accidents, however, within the expected percentage for each year. On the other hand, women have increased their involvement in spreading form; in 2001 were 254 cases and in 2010, 1120, including notably an increase in female participation in traffic accidents.

The study shows that most cases of motorcycle accidents happen between 10 and 29 years of age (55\%), and WHO (1995) considers adolescents ages between 10 to 19 years and 20 to 29 years young adults. In this case, corroborating with the study of Miranda and Sarti [29], which brings in total 51.4\% of cases between the ages mentioned above, as well as other studies [30-32].

In Brazil, the younger crowd is often involved in external causes, coming in many cases to death, among them are the murder, physical violence and traffic accidents. In the previous decade, the number of cases was outrageous, what caused the Brazilian public organizations concerned with policies of prevention of diseases for these purposes [33].

Young people, when start driving, represent a high-risk population for the transit and public health organs, usually by characteristics of inexperience in 
driving, impulsivity, or even the frequent consumption of alcohol, drugs and other, which along with supervisory failure, contribute to the increase in cases of accidents [34-36].

The high number of accidents in this age group can also be explained by the ease and value of the purchase of motorcycles, bearing in mind that at this time there is the insertion in the first job, increasing the purchasing power of the public. In addition, motorcycles have a capacity of faster speed and more precise can be the desired path, especially in urban areas. Is also observed that the acquisition of motorcycles is common, especially among young people, taking into account that traffic with this type of transport, in many cases, provides greater ease of learning compared to a common car, which requires greater coordination in the use of its activities [35, 37].

Is still in discussion the bikes with less than 50 cc, which are quite common in Brazil's Northeastern region, they do not require that the pilot has clearance, and in some places the helmet use is dispensed, compared to this, callings if attention to the number of accidents involving this type of bike, which is recurrent and disturbing [38].

Also noteworthy is that until recently, the hinterland municipalities of the northeast region had no traffic supervisory bodies, and many still do not have the organization, allowing greater traffic minors, persons without a license and using the vehicles wrongly, disregarding traffic laws.

One of the points that make the supervisory process in the Northeastern region is the territorial extension of the municipalities which covers several non-urban areas, thus the competent organs cannot perform an inspection by the high demand of work. This information is consistent with reality, because the municipalities served by the hospital studied are hinterland and mostly do not have supervisory governmental policies [39].

It is important to note the decrease of traffic accidents between 2013 and 2014. There has been a reduction of accidents from 2013 (65\%) and 2014 (34.1\%). This fact can be explained by the intensification of traffic laws and the implementation of new regulatory agencies in the municipalities. The Government of the State of Ceará between these years has modified its fleet of road policing, strengthening and creating just an organ for this purpose, and has implemented new posts along the roads [40].

In addition to increased oversight, stands a further strengthening in prohibition, the prohibition of the use of alcohol in traffic. In 2012, the law went through an intense makeover, decreasing the rate of alcohol to make the breathalyzer test, as well as a greater rigor to the application of penalties [41]. Between 2007 and 2013, higher application process occurred, mostly during holidays and weekends, which can therefore explain the decrease in the indices [42].

In this study, holidays and weekends continue to be the biggest attractions for accidents, even if in a smaller percentage than those of working days. These data, resemble much of the present studies in literature, as in the study of Vieira et al., [43], where $54.5 \%$ of accidents happened over the weekend, already the de Andrade et al., [34] presented 44.3\% of occurrences in the period, corroborating with the present study.

This can be explained because, in this period, many people were off of their jobs, favoring the use of substances. Notes that the inspections of transit, mainly in small towns, are reduced. These evidence can still be related to the culture of young population that go with greater frequency to bars and parties during the weekends, as well as use alcoholic beverages [36].

The abuse of alcohol and the use of the helmet still call attention to the results of this study, even in the face of numerous laws aimed at the reduction of them. In this study, about $61 \%$ of ingested alcoholic substances, corroborating with several studies $[30,31,44]$. However, the study of Franco et al., 
[45] diverges from this result stating that only about $45 \%$ of respondents claimed to have used alcohol. This divergence can be explained by many present feelings of shame in front of the accident, denying the use of substances.

The literature indicate a strong relationship between the use of alcohol and traffic accidents, by the use of that substance to generate a feeling of greater confidence in the conductors at the same step that decreases motor and cognitive activities [44].

Motorcycle accidents that had influence of alcohol tend to be stronger and more impactful for those involved, and may generate severe consequences or even death of drivers and passengers $[45,46]$.

There is a survey conducted by the Brazilian Association for the study of alcohol and Alcoholism, in that after the year 1982, 54\% of work accidents, $51 \%$ of traffic accidents, $20 \%$ of applications for divorce and $60 \%$ of instances officers are directly related to the use of alcohol In addition to more than $80 \%$ of minors abandoned have some alcoholic family member [33].

In this study, the male is who most consumes alcohol, this fact, can be explained by factors already listed, such as the sociocultural and peculiar characteristics of this gender.

In a study carried out in Londrina, Paraná, Brazil, with a total of 3,108 attendances, the men corresponded to $85 \%$ of these, and for the most part, were the drivers of the vehicles. That study, relates to the association occurred when alcohol use and helmet, concluded that male consumes more alcohol than the opposite sex, corroborating with the results of this study $[47,48]$.

The non-use of a helmet is a factor of great concern, since it often results in brain trauma, leading to serious consequences. In our present study, approximately $86 \%$ of patients used helmet at the time of the accident, corroborating with several studies $[42,49]$.
This fact is associated mainly to the study have been carried out in the municipalities, where the practice of not using the helmet is common. In studies conducted in large urban centers the number of people who do not use helmets is lower, as are greater surveillance points, plus passengers are exposed to higher risk situations [42].

The probability of someone using helmet come to develop a brain trauma is smaller in comparison to other that does not uses, since the impact during the accident to one that does not use is higher, if the helmet submit certifications, be within the validity period and being used in a proper way, the chances of developing traumas are minimal $[13,42]$.

Because it is a public hospital in facial and brain trauma care, the number of patients with it is bigger, however, in the literature is found that most of the accidents resulted in traumas of upper and lower limbs [32].

In this study, the incidence of traumas after TBI, followed by the trauma, that relates directly to the non-use of the helmet, i.e., patients who did not use this practice are exposed mostly to brain trauma and facial trauma. Fact noted by several studies that link the TCE to the mostly male, motorcycle drivers in terms of helmet use and not under the influence of alcohol, classifying these victims among vulnerable groups [32, 49].

The characterization of this study serves as an important alert to the development of public health policies that are geared to the prevention of traffic accidents, since in most cases, relates directly to the lack of supervision in smaller municipalities.

\section{Conclusion}

Individuals who are victims of motorcycle accidents are mostly men, from young adult age range, relate the facts to the abusive use of alcohol during weekends and holidays, where most of these accidents have occurred. Between the years 2013 and 2014 
there has been a reduction in the number of accidents and the high rate of trauma and Traumatic brain injury face is directly linked to do not use a helmet.

There's direct influence of these occurrences of traffic on social determinants in health.

\section{References}

1. World Health Organization. Comprehensive report on the status of road safety, 2015. Genebra, Switzerland: 2015.

2. de Oliveira NLB, de Sousa RMC. Ocorrências de trânsito com motocicleta e sua relação com a mortalidade. Revista LatinoAmericana de Enfermagem, 2011; 19(2):403-410.

3. Silva DWD, Andrade SMD, Soares DA, Soares DFPDP, Mathias TADF. Perfil do trabalho e acidentes de trânsito entre motociclistas de entregas em dois municípios de médio porte do Estado do Paraná, Brasil. Cad. saúde pública, 2008; 24(11):2643-2652.

4. Santos AMRD, Moura MEB, Nunes BMVT, Leal CFDS, Teles JBM. Perfil das vítimas de trauma por acidente de moto atendidas em um serviço público de emergência. Cad. saúde pública, 2008; 24(8):1927-1938.

5. Oliveira NLBD, Sousa RMCD. Diagnóstico de lesões e qualidade de vida de motociclistas, vítimas de acidentes de trânsito. Revista Latino-americana de Enfermagem, 2003; 11(6):749-756.

6. de Paula Júnior FJ, Araújo ELL. Análise dos acidentes de trânsito ocorridos em uma Capital do Nordeste Brasileiro, em 2006. Journal of Health \& Biological Sciences, 2012; 1(2):66.

7. Gasparini D. Novo Código de Trânsito-Os municípios e o policiamento. Revista de Direito Administrativo, 2013; 212:175194.

8. Malta DC, Andrade SSCDA, Gomes N, Silva MMAD, Morais Neto OLD, Reis AACD, Nardi ACF. Injuries from traffic accidents and use of protection equipment in the Brazilian population, according to a population-based study. Ciencia \& saude coletiva, 2016; 21(2):399-410.

9. Bacchieri G, Barros AJD. Acidentes de trânsito no Brasil de 1998 a 2010: muitas mudanças e poucos resultados. Rev Saúde Pública, 2011; 45(5):949-63.

10. Vasconcellos EA. O custo social da motocicleta no Brasil. Revista dos Transportes Públicos-ANTP, 2008; 30:31

11. Reichenheim ME, Souza ED, Moraes $C L$, Jorge MHPM, Silva CMFP, Minayo MDS. Violência e lesões no Brasil: efeitos, avanços alcançados e desafios futuros. The Lancet, 2011; 6736(11):7589.

12. Mesquita GV, Santos AMRD, Tapety FI, Martins MDCDC, Carvalho CMRS, Oliveira FAFVD. Análise dos custos hospitalares em um serviço de emergência. Texto \& contexto enferm, 2009; 18(2):273-279.
13. Rodrigues APB, dos Santos AMR, Machado DG, Moura MEB. Characterization of motorcycle accidents attended by service mobile emergency. Revista de Enfermagem da UFPI, 2014; 3(3):73-9.

14. Zabeu JLA, Zovico JRR, Júnior WNP, Neto PFT. Perfil de vítima de acidente motociclístico na emergência de um hospital universitário. Revista Brasileira de Ortopedia, 2013; 48(3):242245.

15. Batista FDS, Silveira LO, Castillo JJAQ, Pontes JED, Villalobos LDC. Epidemiological profile of extremity fractures in victims of motorcycle accidents. Acta ortopedica brasileira, 2015; 23(1):4346.

16. Smith BW, Buyea CM, Anders MJ. Incidence and Injury Types in Motorcycle Collisions Involving Deer in Western New York. American journal of orthopedics (Belle Mead, NJ), 2015; 44(6):E180-3.

17. de Moura EC, Gomes R, Couto Falcão MT, Schwarz E, das Neves ACM, Santos W. Desigualdades de género na mortalidade por causas externas no Brasil, 2010. Revista Ciência \& Saúde Coletiva, 2015; 20(3).

18. Luizaga CTDM, Gotlieb SLD. Male mortality in three Brazilian State Capitals, 1979-2007. Revista Brasileira de Epidemiologia, 2013; 16(1):87-99.

19. Leite Cavalcanti A, Monteiro B, Vanessa B. Mortalidade por causas externas em adultos no município de Campina Grande, Paraíba, Brasil. Sci. med, 2008; 18(4).

20. Morita M, Scarpelini S, Jorge MHPDM, Gawryszewski VP, Dib JA, Pereira Junior GA. Atendimentos de emergência por lesões decorrentes de causas externas: características das vítimas e local de ocorrência, Estado de São Paulo, Brasil, 2005. Cadernos de Saúde Pública, 2008.

21. World Health Organization. Relatório mundial sobre violência e saúde. Genebra: OMS; 2002

22. White $A$, McKee $M$, de Sousa $B$, de Visser R, Hogston $R$, Madsen $S A$, Raine $G$. An examination of the association between premature mortality and life expectancy among men in Europe. The European Journal of Public Health, 2014; 24(4):673-679.

23. de Souza ER. Masculinidade e violência no Brasil: contribuições para a reflexão no campo da saúde. Ciênc Saúde Coletiva, 2005; 10(1):59-70.

24. Costa RG. Saúde e masculinidade: reflexões de uma perspectiva de gênero. Revista brasileira de Estudos de População, 2013; 20(1):79-92.

25. Garcia MAA, Rodrigues MG, Borega RS. O envelhecimento e a saúde. Revista de Ciências Médicas, 2012; 11(3).

26. Gorios C, Souza RMD, Gerolla V, Maso B, Rodrigues CL, Armond JDE. Transport accidents among children and adolescents at the emergency service of a teaching hospital in the southern zone of the city of São Paulo. Revista Brasileira de Ortopedia, 2014; 49(4):391-395 
27. Koizumi MS. Acidentes de motocicleta no Município de São Paulo, SP, Brasil: 2. análise da mortalidade. Revista de Saúde Pública, 1985; 19(6):543-555.

28. Soriano EP, Carvalho MVD, Montenegro JB, Campelo RIC, Almeida AC, Lins Filho JD, Queiroz EGAL. Violência no trânsito: uma década de vidas perdidas em acidentes motociclísticos no Brasil. Derecho y Cambio Social, 2013; 10(31):37.

29. Miranda AL, Sarti ECFB. Consumo de bebidas alcoólicas e os acidentes de trânsito: o impacto da homologação da Lei Seca em Campo Grande-MS. Ensaios e Ciência: C. Biológicas, Agrárias e da Saúde, 2015; 15(6).

30. Rodrigues AIG, Korinfsky JP, dos Santos ADB, de Oliveira ANS, de Almeida LR, Moura LA. Perfil dos usuários atendidos no serviço de emergência em um hospital universitário em Pernambuco. Revista Baiana de Saúde Pública, 2015; 39(1):13.

31. Carvalho ICCM, Saraiva IS. Perfil das vítimas de trauma atendidos pelo serviço de atendimento móvel de urgência. Revista Interdisciplinar, 2015; 8(1):137-148.

32. D'Avila S, Barbosa KGN, de Macedo Bernardino Í, Nóbrega LM, Bento PM, Ferreira EF. Facial trauma among victims of terrestrial transport accidents. Brazilian journal of otorhinolaryngology, 2016; 82(3):314-320

33. Borges LS, Alencar HM. Violence in the Brazilian scenario: risk factors of adolescents facing a contemporary reality. J Hum Growth Dev, 2015; 25(2):194-203. http://dx.doi.org/10.7322/ jhgd.103015.

34. Caetano JÁ, Andrade LMD, Lima MAD, Silva CHCD. Acidentes de motocicleta: características das vítimas e dos acidentes em hospital de Fortaleza-CE, Brasil, 2009.

35. Chumpawadee $U$, Homchampa $P$, Thongkrajai $P$, Suwanimitr $A$, Chadbunchachai W. Factors related to motorcycle accident risk behavior among university students in Northeastern Thailand. Southeast Asian journal of tropical medicine and public health, 2015; 46(4):805-821.

36. Liang CC, Liu HT, Rau CS, Hsu SY, Hsieh HY, Hsieh CH. Motorcycle-related hospitalization of adolescents in a Level I trauma center in southern Taiwan: a cross-sectional study. BMC pediatrics, 2015; 15(1):1

37. Golias ARC, Caetano R. Acidentes entre motocicletas: análise dos casos ocorridos no estado do Paraná entre julho de 2010 e junho de 2011. Ciênc Saúde Coletiva, 2013; 18(5):1235-46.

38. Souza ARD, Vasconcelos TSL. Transporte E Mobilidade Urbana: O Fluxo De Motocicletas Em Mossoró, RN. Revista Geotemas, 2016; 6(1), 67-81

39. Santos AMRD, Rodrigues RAP, Santos CBD, Caminiti GB. Geographic distribution of deaths among elderly due to traffic accidents. Escola Anna Nery, 2016; 20(1):130-137.

40. Brasil. Governo do Estado do Ceará. Secretaria de Segurança Pública. Governo vai construir 10 novos postos da polícia rodoviária estadual. Fortaleza, Ceará, Brasil: 2014.
41. Oliveira AS, Pedro JB, Mamlak L, Oliveira LS, Mendonça LO, Santiago MF, Santos WF. A nova lei seca: mudanças ocasionadas pela antiga e nova lei no código de trânsito brasileiro. Caderno de Graduação-Ciências Humanas e Sociais-UNIT, 2014; 2(2):137146.

42. Malta DC, Berna RTI, Silva MMA, Claro RM, Silva Júnior JB, Reis AAC. Consumo de bebidas alcoólicas e direção de veículos, balanço da lei seca, Brasil 2007 a 2013. Revista de Saúde Pública, 2014; 48(4):692-966.

43. Vieira RDCA, Hora EC, Oliveira DV, Vaez AC. Levantamento epidemiológico dos acidentes motociclísticos atendidos em um Centro de Referência ao Trauma de Sergipe. Revista da Escola de Enfermagem da USP, 2011; 45(6):1359-1363.

44. Duailibi S, Pinsky I, Laranjeira R. Prevalência do beber e dirigir em Diadema, estado de São Paulo. Rev Saude Publica, 2007;41(6):1058-61.

45. Franco MSP, de Lima Lins AC, de Araújo TLC, Amaral RC. Caracterização de pacientes vítimas de acidentes de transito admitidos em hospital regional da Paraíba. Revista Interdisciplinar, 2015; 8(2):129-135.

46. Tavares FL, Coelho MJ, Leite FMC. Men and motorcycle accidents: characterization of accidents from pre-hospital care. Escola Anna Nery, 2014; 18(4):656-661.

47. Carneiro FVP, Jorge MSB, Batista FLR. O alcoolismo e suas consequências: aspectos físicos e psíquicos. Rev. RENE, 2005; 6(1):54-61.

48. Kobayashi CR, de Carvalho MS. Violência urbana: acidentes de trânsito envolvendo motociclistas na cidade de Londrina (PR). Geografia (Londrina), 2013; 20(3):171-190.

49. Harmon KJ, Marshall SW, Proescholdbell SK, Naumann RB, Waller AE. Motorcycle crash-related emergency department visits and hospitalizations for traumatic brain injury in North Carolina. The Journal of head trauma rehabilitation, 2015; 30(3), 175-184.

Publish in International Archives of Medicine

International Archives of Medicine is an open access journal publishing articles encompassing all aspects of medical science and clinical practice. IAM is considered a megajournal with independent sections on all areas of medicine. IAM is a really international journal with authors and board members from all around the world. The journal is widely indexed and classified Q2 in category Medicine. 